\title{
The Role of Family Ownership in the Relationship between Board Characteristics and Corporate Social Environmental Reporting: Evidence from Malaysia
}

\author{
Fathyah Hashim, Zaini Embong \& Wang Boon Phoey
}

\begin{abstract}
The objective of this paper is to investigate the role of family ownership in the relationship between board of directors (BOD) characteristics and the reporting of corporate social and environmental practices (CSER). BOD is one of the corporate governance mechanism put in place to ensure that the company is managed to the best interest of shareholders. However, previous findings on the relationship between BOD characteristics and CSER are inconclusive. The effectiveness corporate governance mechanisms including BOD characteristics is claimed to be influenced by cultural and societal norms. Hence, this study adds to the understanding of the role of BOD in reporting practices of companies in Malaysia. In addition, given the mixed findings on the relationship of BOD and CSER, this study also investigates the role of family ownership. This paper suggests that the relationship between BOD and CSER is weaker in family-owned companies because the owner tends to safeguard the information, hence lower disclosure is evidenced. Malaysia is unique in the sense than around 70\% of companies are owned by families and this provide a good setting for the study. Cross-sectional sample of 136 public listed companies are selected using systematic stratified random sampling methods. BOD characteristics to be investigated are female on Board (FB), board independence (BI), board size (BS) and CSR committee (CC). The CSER is assessed by content analysis, and PLS-SEM is used for data analysis. The results indicate that all of the BOD characteristics tested in this study except for board size, have significant positive relationship with CSER. However, the moderating role of family ownership is not supported.
\end{abstract}

Keywords: Family ownership; board characteristics; corporate social and environmental reporting; corporate governance; Malaysia; disclosure

\section{INTRODUCTION}

Corporate social and environmental reporting (CSER) refers to companies' disclosure about societal and environmental performance, including information about human resource related practices, community involvement activities and projects, quality and safety of products and services, and environmental contribution (Ali \& Rizwan 2013). Environmental issues such as global warming, food security and water pollution are still in growing concern globally. More recently, the issues on employees' welfare receives increasing attention. Forced labor, poor living condition and child labor are among aspects that receive global attention. The recent case of Top Glove (Channelnewsasia 2020) is one of the examples that can illustrate how social responsibility of a company can affect the reputation and performance of the company. Malaysia is also committed to the Agenda 2030 for Sustainable Development and mandated relevant corporate social responsibility reporting for all public listed companies. Findings by Noradiva and Maizatulakma (2018) indicates that stakeholders in Malaysia perceive CSER as important, however, empirical evidence also shows that CSER level in Malaysia is still low (Anas et al. 2015). Findings from previous studies indicate that one of the factors that contributes to the CSER is board of directors (BOD) characteristics. Empirical findings on the relationships between BOD characteristics and CSER are however inconclusive. For example, board independence is found to be positively related to disclosure in Pakistan (Rafique et al. 2017), Australia (Rao et al. 2012) and China (Huafang \& Jianguo 2007) but negative in Kenya (Barako et al. 2006) and insignificant with regard to CSR disclosure in Malaysia (Yusoff et al. 2019).

The relationship between board characteristics and disclosure can be explained using agency cost theory. The board of directors is put in place as a monitoring mechanism to align the action of managements to the best interest of the owners. One of the outcomes of effective monitoring is more transparency or higher disclosure level. The empirical findings on the relationship between board characteristics and disclosure level are however inconclusive, indicating that there may be a variable that moderates this relationship. Agency cost is said to be low in family owned companies because it is often assumed that ownership and management are aligned within the same family, hence reduce the need for higher disclosure. Therefore, based on agency theory, the need to disclose may be less in family owned companies. Hence, given the same board characteristics, we hypothesize that the influence on CSER disclosure is different for family owned companies. In other words, family ownership moderates the relationship between board characteristics and CSER disclosure. There is yet an 
empirical investigation on the role of family ownership in the relationship between board characteristics and disclosure. The corporate ownership structure in Asia including Malaysia is highly concentrated compared to the western countries and family owned companies are common in Malaysia (Ainon 2018), providing a good sample for this study. There are quite a number of studies that investigate the relationship between CSER and BOD characteristics such as Abdullah et al. (2011) that investigate the direct relationship between independent directors, family members on board and government ownership with CSR disclosure. Similarly, Ahmad et al. (2018) also investigate direct relationship between board gender diversity and CSR disclosure. The same goes with Akbas (2016) and Intan Maiza and Ku Nor Izah (2016) where these papers investigate the direct relationship between board characteristics and CSR disclosure. Although the studies on CSER and BOD characteristics are plenty, the relationship need to be re-investigated in different environment especially Asia where the culture is different (Chang et al. 2017). Our study is also different in the sense that we investigate the role of family ownership in the relationship between board characteristics and CSR disclosure. The moderating role of family ownership is to our knowledge has yet to be empirically investigated and through this study we have provided evidence that board of directors is able to professionally perform their duty even when in a family-controlled companies. Hence, this study intends to investigate not only the relationship between BOD characteristics and CSER but also the role of family ownership in that relationship. Malaysia is unique in the sense that around 7 in 10 companies are family-owned, and family members account for $85 \%$ of company board membership (Azmi \& Barrett 2013). Agency cost between management and owners is low in family owned companies although agency cost type two between majority and minority shareholders is high. However, since the owner has more control over the conduct of the company, this paper suggests that the relationship between BOD characteristics and CSER is weaker in a family owned companies.

Corporate social and environmental reporting can be considered as one of the communication tools used by companies to relay information regarding the effect on social and environment effect from its economic activity. The purpose could be to fulfill listing requirements, legitimacy purpose (Gray et al. 2001) or to signal its performance to stakeholders (Sweeney \& Coughlan 2008). CSER can also be seen as expression of the commitment for the social and environmental issues, in such a way it is also an indication of corporate moral consciousness (Shearer 2002), and an important tool for decision making (Shil \& Paramanik 2009). The increasing demand for business to be more socially responsible (Chapple \& Moon 2005), the mandatory CSR disclosures requirements, as well as increasing stakeholders' perception and awareness on the social and environmental issue are among external factors that lead companies to disclose corporate activities that may affect environment and social wellbeing (Mamun et al. 2017; Kilian \& Henning 2014). Given these circumstances, there is possibility for companies to provide only positive information to portray a positive image (Buniamin et al. 2008), thus creating further interest in the authenticity of the CSER.

Corporate agents especially the board of directors and the management who are relevant for the decision and implementation of the CSER play a crucial role in ensuring the quality and reliability of the report (Alshareef \& Sandhu 2015). Corporate governance (CG) is the mechanism that drives corporate behavior and one of the most important components in CG mechanism is the board of directors (BOD). BOD not only monitors the management but also ensures the company complies with all the regulations, including disclosure of CSR (Buniamin et al. 2008) as well as strategic decisions that benefit shareholders. Good governance able to affect corporate behavior, decision making, enhance the management conduct and increase operation efficiency as well as reporting level (Alshareef \& Sandhu 2015; Yusoff et al. 2019). However, CG practices including board characteristics vary given different environments. The effectiveness of $\mathrm{CG}$ is influenced by legal and regulatory frameworks as well as cultural factors (Maher \& Andersson 1999). The empirical evidences of the CG and the extent of the CSER in Malaysia are inconsistent. One of the possible explanations to these inconclusive findings could be the ownership structure of companies in Malaysia. It is reported that $70 \%$ of companies in Malaysia are family-owned, and family members account for $85 \%$ of board membership (Azmi \& Barrett 2013). Besides, the next generation of family members are found working in $69 \%$ of Malaysian family business (Price Waterhouse Coopers 2016). Sundarasen et al. (2016) state that family-owned companies are deemed to lack in CSR initiatives and are also found to negatively related to CSER disclosure as well as voluntary disclosure.

Board of directors as one of important elements in corporate governance mechanism can influence the practice of the company including reporting policy. Empirical evidence shows that BOD characteristics such as female on board (Phua \& Chua 2017), board independence (Htay et al. 2012), board size (Fauzi \& Locke 2012) and CSR committee (Baraibar-Diez \& Odriozola 2019) relates positively to CSER. However, there are also research findings that show negative relationship (Barako et al. 2006) for board independence and insignificant findings (Ahmad et al. 2018; Yusoff et.al. 2019; Masud Nurunnabi \& Bae 2018) for female on board, board independence and CSR committee. The inconsistency in previous findings motivates this study to investigate the role of family ownership in the relationship between board characteristics and CSER in Malaysia. As stated above, majority of companies in Malaysia are family-owned and previous findings also indicate that transparency or disclosure level for family-owned companies are lower 
(Abdullah et al. 2011). Agency theory explains that companies increase disclosure to avoid pressure from regulatory authorities, while CG mechanism such as BOD is important to guide and monitor the corporate agent to uphold company image and reputation to public. Panda and Leepsa (2017) in their review suggest that the agency theory assumes that contracting can eliminate the agency problem, but practically it faces many hindrances like information asymmetry, rationality, fraud and transaction cost. Given that agency cost type one is lower in familyowned companies, this paper proposes that the positive relationship between board characteristics and CSER would be weaker due to the possible exertion from the owners, hence weaken the effectiveness of BOD. This paper therefore contributes to the literature as there is yet and empirical evidence on whether or not ownership structure moderates the relationship between BOD characteristics and CSER. The findings may also be used as a guideline in determining the board structure in order to enhance the CG mechanism in Malaysia. The paper proceeds with hypothesis development followed by methodology, discussion of the findings and conclusion.

\section{Literature Review And Hypothesis Development}

Corporate social and environmental reporting (CSER) is a supplementary disclosure in corporate reporting to inform society about their social and environmental rights (Hassan 2010). CSER is one of the tools that is designed to draw attention and to communicate with either external or internal stakeholders such as government agencies to influence the users (Sweeney \& Coughlan 2008), therefore companies may simply produce a positive form of report to depict positive image to the stakeholders (Buniamin et al. 2008). Factors that affect CSER have been studied and can been categorized into three groups (Adam 2002) that are corporate characteristics, general contextual factors and internal contextual factors. The first category, corporate characteristics is the most studied determinant, for example company size and type (Rosli \& Mohd 2015, 2018), ownership structure (Bani-Khalid et al. 2017), board composition (Hussain et al. 2018), and financial performance (Yap et al. 2017). Generally, inconclusive findings are found in support with Haider (2010) review.

Although CSER has been mandated by Bursa Malaysia, the reporting disclosure items are still largely based on management discretion since the guidelines and specification remains as outlines (Fatima et al. 2015). There are various studies examining the relationship between ownership structure and the disclosure level with mixed findings. Bani-Khalid et al. (2017) for example finds negative relationship between ownership structure and voluntary disclosures in Jordan, while Alhazmi (2017) finds positive relationship between ownership structure and social responsibility disclosures in Saudi Arabia. In Malaysia, Ghazali (2007) finds that owner managed companies disclosed significantly less CSR information but companies with substantial government shareholding disclose significantly more CSR information in their annual report. In family-owned companies, the family members act as the director and actively involved in the management (Ho \& Kang 2013), hence are expected to have less severe agency conflict with the management team but may face more agency conflict between the minority and majority shareholders (Cheng 2014). Agency theory stipulates that separation of ownership and control can result in a conflict of interest between management and shareholders (Fama \& Jensen 1983). Hence, BOD is put in place to monitor and align management to act in the best interest of the owners. To function as monitoring mechanism effectively, the agency theory indicates that a large number of independent outside directors and separation of the role of chief executive officer (CEO) and chairman of the BOD is important. Hence, the more diverse the composition or characteristic of BOD, the more effective the BOD at monitoring the management. In relation to our study, we contend that the more diverse the BOD such as having female on board and independent members will lead to better monitoring mechanism, hence lead to better CSER disclosure. The components of BOD and how it relates to CSER are further discussed in the following sections.

FEMALE ON BOARD AND CORPORATE SOCIAL AND ENVIRONMENTAL REPORTING

The presence of females on board could add different perspectives and diversity of board. Gender diversity affects the board's critical function of monitoring management, adding qualified female board members can enhance the range of professional experiences which enable the board to be more effective in monitoring management (Hillman \& Dalziel 2003). Nielsen and Huse (2010) finds board composition with female members positively affect the broad strategic control. Study by Sundarasen et al. (2016) notes that female board members plays an important role in enhancing corporate reputation through CSR initiatives while Phua and Chua (2017) finds positive relationship with environmental disclosure in Malaysia. A study by Xie (2018) in China also finds that proportion of female executives in the board of directors is positively associated with the amount of corporate charity.

There are however also reported findings that show insignificant relationship between female board members' ratio and disclosure level, for example in Malaysia (Ahmad et al. 2018), USA (Giannarakis 2014) and Pakistan (Rafique et al. 2017). In 2019, there are about $28.6 \%$ of female members on board of directors in Malaysia, an improvement from 8\% in 2010 (Statista 2020). Malaysia aims to achieve the target of $30 \%$ female board members in the top public listed companies in 2020 , thus female on board is seen to have increased in number from the regulator pressure based on the institutional theory. 
More female on board is also associated with less earnings management (Liu et al. 2016) and more risk averse leading to better monitoring and control (Hillman $\&$ Dalziel 2003). Given the more prominent findings that female on board (FB) is positively related to CSER, this study hypothesized that more female in BOD can be associated with higher CSER.

$\mathrm{H}_{1}$ : The number of females on board is positively related to CSER.

BOARD INDEPENDENCE AND CORPORATE SOCIAL AND ENVIRONMENTAL REPORTING

Board independence (BI) is a concept in corporate governance that calls for a majority of the members of board of directors to be independent from the company, free from any business or relationship that could interfere with the exercise of independent judgement. In accordance with MCCG 2017, at least one half of the board has to comprise of independent directors. Independent directors tend to encourage companies to publish more relevant information to stakeholders and thus place pressure on the company to ensure that the company is managed sustainably (Certo et al. 2001). Independent directors who are neither holding significant ownership nor executive position in a company have greater monitoring and controlling ability over management (Fama \& Jensen 1983). It is expected that the independent directors represent the other stakeholders' interest and will have more influence on environmental reporting (Haniffa \& Cooke 2005). Independence directors are believed to protect or defend shareholder and shareholders' interest and increase the level of disclosure (Rafique et al. 2017). Positive relationship between $\mathrm{BI}$ and disclosure level have also been found in different countries such as Pakistan (Rafique et al. 2017), Australia (Rao et al. 2012), China (Huafang \& Jianguo 2007) and Bangladesh (Khan et al. 2012).

A study in Kenya (Barako et al. 2006) however finds negative relationship between BI and voluntary disclosure. There are also studies that find the relationship to be insignificant such as in Bangladesh (Saha \& Akter 2013) and the USA (Giannarakis 2014). Studies using Malaysian sample that reports insignificant relationship between BI and disclosure includes Janggu et al. (2014) on sustainability disclosure, Yusoff et al. (2019) and Said et al. (2009) regarding CSR disclosure and Buniamin et al. (2008) on environmental disclosure. To formally test the relationship between BI and CSER, based on the more common findings, the following hypothesis is developed:

$\mathrm{H}_{2}$ : Board independence is positively related to CSER

\section{BOARD SIZE AND CORPORATE SOCIAL} AND ENVIRONMENTAL REPORTING

Board of directors is one of the corporate governance mechanisms that provide important monitoring and align the interest of shareholders and management. From the perspective of agency theory, the board of directors can be used as monitoring mechanism to monitor executives' behavior on behalf of shareholders (Fama \& Jensen 1983). When the board is able to provide richer information, the top management and executives are more likely to act consistent with shareholders' interest (Eisenhardt 1989). Coles et al. (2008) state that larger firm needs larger board size due to the diversified business. Larger board may mean more diversity in terms of educational, sociological background, field of expertise, skills and experience that may improve firm value (Bukair \& Abdul-Rahman 2015). Diversity in board composition may also contribute to the sharing of CSR-related initiatives (Fauzi \& Locke 2012), the experience sharing subsequently may increase CSR involvement (Esa, Anum \& Ghazali 2012) and hence the reporting of these CSR activities. The CSER disclosure requires full involvement of all directors and requires effective communication among directors. Hence, there are plenty of empirical evidence of positive association between board size and CSER, for example in Malaysia (Zulkiflee 2016), Pakistan (Rehman et al. 2017) German (Dienes \& Velte 2016) and Jordan (Ghabayen et al. 2016).

There are on the other hand studies that find larger board size causes ineffective communication which in return lead to poor decision making and hence hinders directors from executing their roles effectively (Said et al. 2009). It is argued that smaller board is more efficient than larger board due to increasing agency cost in larger board size, and larger board are also deemed to be weak in management control (John \& Senbet 1998). There are also some studies that find no significant relationship between board size and disclosure level, for example in Malaysia (Said et al. 2009) and Bangladesh (Rouf \& Hossan 2020).

Despite the mixed findings, the more common empirical evidence shows that there is a positive association between board size and CSR disclosure. Thus, to formally test on the relationship between board size and CSER, the following hypothesis is developed:

$\mathrm{H}_{3}$ : Board size is positively related to CSER

\section{CSR COMMITTEE AND CORPORATE SOCIAL} AND ENVIRONMENTAL REPORTING

Bursa Malaysia has defined CSR in item (29) of Appendix 9C as a concept that focuses on a corporation's behavior and actions. It has been defined as transparent business practices based on ethical values and the respect for community, employees, environment, shareholders and other stakeholders which the corporations integrating socially responsible behavior into business. Prior to the mandatory CSR disclosure in the annual report of the public listed companies in Malaysia in 2007, the CSR disclosure is voluntary. Malaysia has aligned the CSR programs as one of the national goals in $11^{\text {th }}$ Malaysia Plan and sustainable development goals (SDG), and 
introduced tax incentives for business implementing CSR activities in order to promote CSR activities. Although Bursa Malaysia has outlined CSR requirements and framework for the listed companies to comply, it does not prescribe clearly on the disclosure contents

In accordance with agency theory, higher disclosure reduces information asymmetry and this may reduce conflict of interest between shareholders and management, and management can be made accountable for their conducts (Htay et al. 2012). The CSR committees are expected to be in line with the principal's interest to stimulate the management to be more accountable. The CSR committee's existence symbolizes the board orientation and the corporation commitment towards sustainable development. Its existence allows the company to oversee the company's CSR activities and disclosure practices which are in the principal's interest.

In Malaysia, although Bursa Malaysia requires companies to disclose the CSR activities in annual reports, the formation of CSR committee is not compulsory. CSR committee is found to positively related to sustainability reporting in Spain (Baraibar-Diez \& Odriozola 2019) and to CSR disclosure in the United State of America (Giannarakis 2014). However, there is no significant relationship between CSR committee with environmental sustainability reporting in South Asian countries (Masud et al. 2018). There is however lack of documented research on the CSR committee and its relationship with CSER in Malaysia. Given this background, this study hypothesizes the following:

\section{$\mathrm{H}_{4}$ : CSR committee is positively related to CSER}

\section{THE ROLE OF FAMILY OWNERSHIP}

In Malaysia, around 7 in 10 companies are family-owned, and family members account for $85 \%$ of company board membership (Azmi \& Barrett 2013). The study by Yasser (2011) defines family-controlled business as those enterprises which are either owned, controlled, or drastically influenced by a specific family or families and have significant dominant position in firms' equity. According to Amran (2010) a family-controlled company is defined by Malaysian rules and regulations as a company that fulfils three criteria; (1) Founding CEO is the CEO or the inheritor of the CEO is related by blood or marriage, (2) at least two family members in its management team, and (3) family directors' own equity at least $20 \%$ in the company.

The ownership pattern has changed over time, family ownership (FAM) is being defined in various ways in accordance with the study being undertaken at the time, and generally defined based on the degree of ownership and/or management by family members (Ibrahim \& Samad 2010). The family-owned companies are more likely to have female board members in Malaysia, and in other countries, the dominant family ownership in a company contributes as the main factor to a higher proportion of female board members (International Finance Corporation 2019).

The type of controlling shareholders which may be individual, family holdings or other corporations acting through holding companies can significantly affect the behavior of the company that they are trying to control (OECD 2004). Various studies examine the effect of ownership structure on corporate performance and the disclosure level, and the findings of previous studies show negative relationship between the ownership structure and voluntary disclosure in Jordan (Bani-Khalid et al. 2017), Kenya (Barako et al. 2006) and Bahrain (Juhmani 2013). However, government ownership has been found to be positively related to the sustainability disclosures in Swedish (Persson \& Vingren 2017) and also with social responsibility disclosures in Saudi Arabia (Alhazmi 2017).

In Malaysia, Ghazali (2007) reveals that owner managed companies disclose significantly less CSR information but the government linked companies (GLC) disclose significantly more CSR information in their annual report. In family-owned companies where family members act as director and actively involved in the management (Ho \& Kang 2013), agency conflict with the management team is expected to be less severe but agency conflict between the minority and majority shareholders may be more severe due to expropriation by owners (Cheng 2014). Since the management may consist of family members who are also the owner of the companies, there may be less incentive to disclose more. Hence, in this situation, the effectiveness of BOD may be reduced.

Family-controlled business is found not to contribute to the CSR initiatives nor contribute towards humanizing CSR (Sundarasen et al. 2016), thus negative association between the family ownership and CSR disclosure are documented by previous studies, for instance in Malaysia (Abdullah et al. 2011) and in Hong Kong (Ho \& Wong 2001). However, there are studies that show insignificant relationship between family ownership and CSR disclosure in Kuwait (Al-Shammari \& Al-Sultan 2010) as well as ownership and voluntary disclosure in Malaysia (Ghazali \& Weetman 2006). There are a number of studies on the relationship between ownership structure and CSER, however, evidence on the role of family ownership in the relationship between BOD and disclosure especially CSER is yet to be provided. In other words, based on agency theory, BOD with diverse characteristics can be an effective monitoring mechanism and align the action of management to the best interest of the owners and other stakeholders including disclosing more information. However, when the company is owned by family, the need to disclose more information may become less because the agency cost type one is lower. Hence, given the same board characteristics, we expect the positive relationship between BOD characteristics and CSER to be weaker in a family-owned companies. Thus, in order to formally test the role of family ownership in 
the relationship between board characteristics and CSER, the following hypotheses are developed:

$\mathrm{H}_{5 \mathrm{a}}$ : The positive relationship between female on board and CSER is weaker in family-own companies

$\mathrm{H}_{5 \mathrm{~b}}$ : The positive relationship between board independence and CSER is weaker in family-own companies

$\mathrm{H}_{5 \mathrm{c}}$ : The positive relationship between board size and CSER is weaker in family-own companies

$\mathrm{H}_{5 \mathrm{~d}}$ : The positive relationship between CSR committee and CSER is weaker in family-own companies

\section{Methodology}

This section discusses research design, sample selection as well as measurement of variables. The independent variables consist of female on board (FB), board independence (BI), board size (BS) and CSR committee (CC) to represent board characteristics. The source of data is from annual report of companies included as sample. Content analysis of the annual report is also performed to measure the CSER level of companies. Information on family ownership, FAM is also gathered from annual report.

\section{Research Design}

This study aims to examine the relationship between CSER and female on board (FB), board independence (BI), board size (BS) and CSR committee (CC), as well as the moderating effect of family ownership (FAM). The data is collected from the company's published electronic format annual report. CSER related information publicized through channels other than the published annual report such as press release, website and conference call are excluded. The annual report is an important source of information for stakeholders that is seen as highly credible, and one of the most accessible reports of the public listed companies in Bursa Malaysia website (Haniffa \& Cooke 2005).

This study is a cross-sectional study using data at the specific point in time (2019) for a defined population (public listed companies on Main Market of Bursa Malaysia). Cross sectional study is used due to its simplicity to conduct and usually does not pose much of a challenge from an ethical viewpoint (Aggarwal \& Ranganthan 2019).

\section{POPULATION AND SAMPLES}

The population of this study is all public listed companies on Bursa Malaysia's Main Market. There are 783 companies across 15 sectors as of $13^{\text {th }}$ September 2020. All financial firms (52 companies) and special purpose acquisition company (one company) are excluded from the sample as these sectors have significant differences in terms of its corporation and operation structure, and are governed by different rules and procedures from regulatory bodies such as Bank Negara Malaysia and the Ministry of Finance, consistent with previous research such as Buniamin et al. (2008).

Minimum size sample is determined using10-times rule method (Barclay et al. 1995) and the calculation indicates minimum sample of 120 . From the sample selection procedure, the final sample of this study consist of 136 companies. Stratified random sampling method is applied to select the companies from Main Market of Bursa Malaysia that represents a diverse range of the eleven industry sectors from the non-financial firms to ensure representative sample of the total population (Said et al. 2018). Table 1 presents the final number of companies included in the sample.

TABLE 1. Population and sample

\begin{tabular}{lccc}
\hline Sector & Population & $\%$ & Sample \\
\hline Construction & 51 & 6.98 & 4 \\
Consumer Products \& Services & 172 & 23.53 & 40 \\
Energy & 31 & 4.24 & 1 \\
Health Care & 13 & 1.78 & 1 \\
Industrial Products \& Services & 224 & 30.64 & 69 \\
Plantations & 43 & 5.88 & 3 \\
Properties & 96 & 13.13 & 13 \\
Technology & 40 & 5.47 & 2 \\
Telecommunications \& Media & 17 & 2.33 & 1 \\
Transportation \& Logistics & 32 & 4.38 & 1 \\
Utilities & 12 & 1.64 & 1 \\
Total & 734 & 100.00 & 136 \\
\hline
\end{tabular}


The number of companies included in the sample mirrors the determined percentage of companies in a particular sector compared to population. For example, there are 51 companies in the construction sector and this represents $6.98 \%$ of the population. Hence, four companies that is $6.98 \%$ from 51 are selected as sample for this study. Applying the same method to all the sectors brings the final sample to 136 companies.

\section{MEASUREMENT OF VARIABLES}

CSER practices is the dependent variable of this study. Content analysis is a technique used to measure the level of CSER (Hamid \& Atan 2011), and employed by this study to measure CSER disclosure value. The research instruments in this study consists of two aspects relevant to CSER which are environment and social, adapted from the Disclosure Index Instrument (DII) used by Joseph (2010). There are three steps to develop CSER checklist for content analysis: 1) Refer Joseph (2010) DII for environment and social items list, 2) Remove 'Economy' theme and 'Local Agenda 21 Program' relevant items from Joseph (2010) DII and 3) Construct CSER checklist for content analysis. Similar content analysis is adopted by previous studies for the evaluation of the sustainability practices' disclosure (Hashim et al. 2015), and for the evaluation of corporate risk exposure (Mazurina \& Taylor 2014).

This study's content analysis examines the presence of information or items based on the developed CSER checklist (refer to Appendix 1). The checklist contains 38 CSER items, and the scores are based on an unweighted method where all the information given has an equal weight or value regardless of their importance (Chau \& Gray 2002). This method has been adopted by CSER studies in Malaysia such as Ahmad et al. (2018) and Abdullah et al. (2011), where ' 1 ' is given for the disclosed item and ' 0 ' if it was not disclosed. Thus, the overall CSER disclosure index (CSERI) is the summation of the scores of all the CSER items, which are measured by computing the ratio of the scores obtained to the total score (i.e. 38) by a particular company. The measurement of all other variables is presented in Table 2 .

TABLE 2. Summary of variables' measurement

\begin{tabular}{|c|c|c|c|}
\hline Type of Variable & Variables & Measurement & Sources \\
\hline $\begin{array}{l}\text { Dependent Variable } \\
\text { (DV) }\end{array}$ & $\begin{array}{l}\text { Corporate Social } \\
\text { and Environmental } \\
\text { Reporting (CSER) }\end{array}$ & $\begin{array}{l}\text { The CSER is measured based on the developed CSER } \\
\text { checklist which includes two aspects: environment } \\
\& \text { social. It is indicated by the presence of the CSER } \\
\text { items: ' } 1 \text { ' if the items/ information present and ' } 0 \text { ' } \\
\text { if items absence. }\end{array}$ & Joseph (2010) \\
\hline
\end{tabular}

Independence Variables (IV)

$\begin{array}{ll}\begin{array}{l}\text { Moderating Variable } \\ \text { (MV) }\end{array} & \begin{array}{l}\text { Family Ownership } \\ \text { (FAM) }\end{array} \\ \begin{array}{l}\text { Control Variables } \\ \text { (CV) }\end{array} & \text { Profitability (ROA) }\end{array}$
(CV) (BI)

Board Size (BS)
Female on Board (FB) The FB is measured by the percentage of women directors to total directors on board

Said et al. (2018), Yusoff et al. (2019), Rao et al. (2012)

Board Independence The BI is measured by the percentage of the independent director on board of directors

CSR Committee (CC)

The BS is measured by the number of directors on the board

The $\mathrm{CC}$ is measured by the existence of a CSR or sustainability committee, and this is a dummy variable where if the company has a CSR committee it is equal to ' 1 ', and ' 0 ' if the company don'ts not have a CSR committee.

The FAM is measured by the percentage of family members on board of directors

The profitability measured by ROA which is the return on the assets, calculated by the percentage of profit after tax over total assets of company.

Firm Size (FIR)

Sector (SEC)
Ganesan et al. (2017), Akbas et a.l (2016), Yusoff et al. (2019)

Buniamin et al. (2008), Said et al. (2009), Ganesan et al. (2017), Said et al. (2018)

Baraibar-Diez \& Odriozola (2019)

Abdullah et.al. (2011)

Ganesan et al. (2017), Said et al. (2018)

Said et al. (2009), Ganesan et al. (2017), Said et al. (2018)

Buniamin et al. (2008),

Ganesan et al. (2017)
The firm size is measured by the natural log of the total assets of companies reported in annual report

The sector which companies listed under Bursa Malaysia Main Market: (1) Construction, (2) Consumer Products \& Services, (3) Energy, (4) Health Care, (5) Industrial Products \& Services, (6) Plantations, (7) Properties, (8) Technology, (9) Telecommunications \& Media, (10) Transportation \& Logistics, (11) Utilities 


\section{Results AND Findings}

Two key analyses are performed namely descriptive analysis and statistical analysis. The descriptive analysis is used to identify the CSER level in public listed companies of the eleven sectors in Bursa Malaysia's Main Market and statistical analysis is performed to investigate the relationship between BOD characteristics and CSER as well as the moderating role of family ownership employing SmartPLS tool.

\section{DESCRIPTIVE ANALYSIS}

The frequency analysis on variables is done to check sample validity and if there was missing data point for each variable. Table 3 presents descriptive statistics of all variables of this study.

TABLE 3. Descriptive statistics of variables

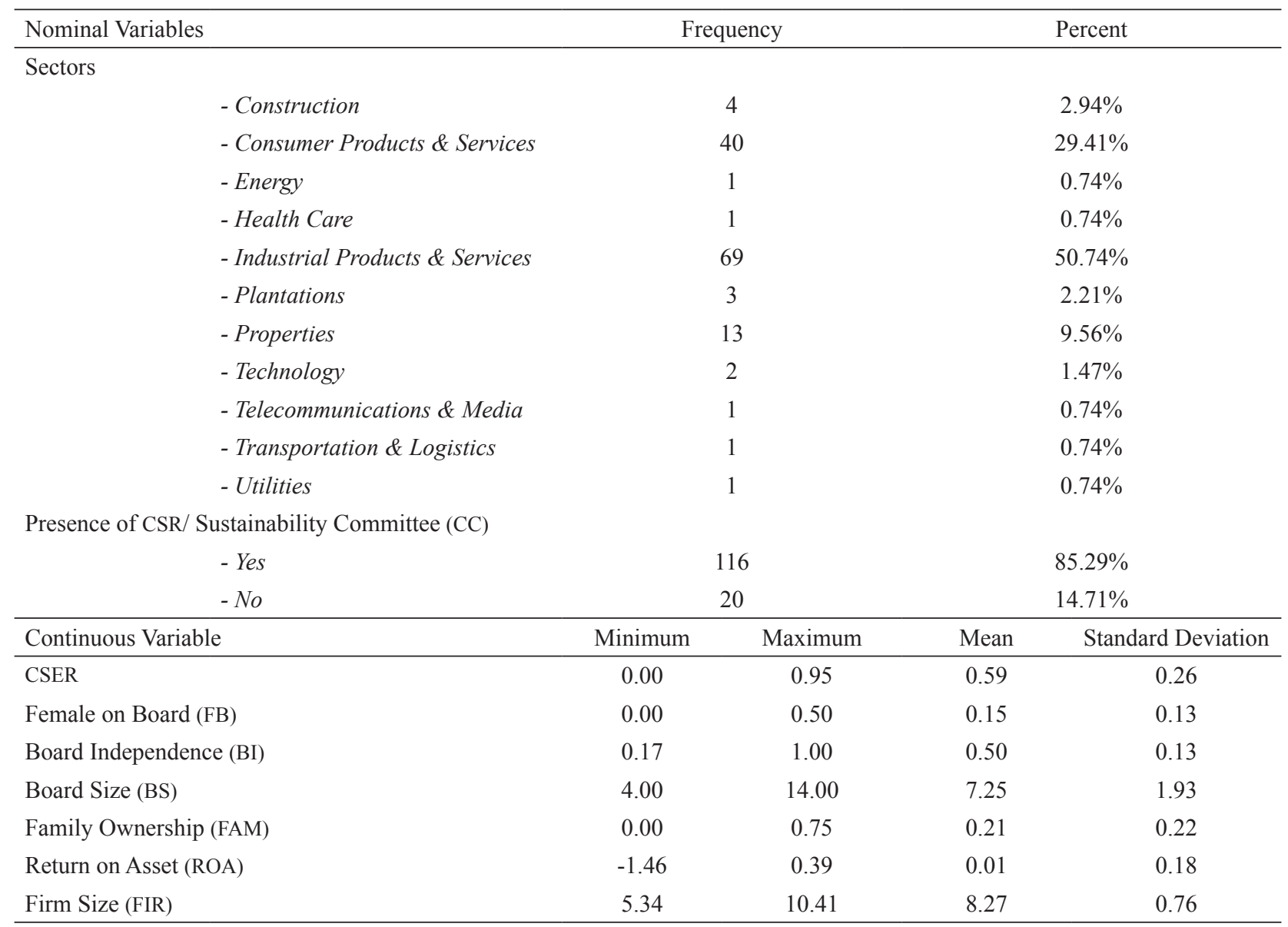

Industrial products and services sector have the highest number of companies in this study (50.74\%), followed by consumer products and services sector $(29.41 \%)$, properties sector $(9.56 \%)$, construction sector (2.94\%), plantations (2.21\%), technology (1.47\%), energy $(0.74 \%)$, health care $(0.74 \%)$, telecommunications and media $(0.74 \%)$, transportation and logistics $(0.74 \%)$ and utilities $(0.74 \%)$. The results also indicate that there are $85.29 \%$ of companies having CSR/sustainability committee in their structure, and $14.71 \%$ without this committee in their companies.

For the continuous variables, there are minimum $0 \%$ and maximum $50 \%$ of female on board shown in the sample. The mean (standard deviation) for female on board is $0.15(0.13)$, which means on average there are $15 \%$ female on board in the companies in this study. Mean (standard deviation) of board independence is 0.50 
(0.13) with the minimum $17 \%$ and maximum $100 \%$, indicating that there are on average $50 \%$ of the board members are independent directors. Mean (standard deviation) of board size is 7.25 (1.93) showing that on average there is 7 directors in board, with the minimum 4 and maximum 14 members. The family ownership is measured from the percentage of family member in the board and the result in Table 3 shows that percentage of family member in the board ranges from $0 \%$ to $75 \%$ with an average of $21 \%$. Companies with $0 \%$ family member on board is considered as non-family owned companies.

The control variables included in this study are variables found by previous studies to influence disclosure level and these are return on asset (ROA), firm size (FIR) and sector. For ROA the minimum is $-146 \%$ and maximum $39 \%$ with mean of $1 \%$. The firm size measured by natural $\log$ of total assets shows a minimum of 5.34 and maximum of 10.41 with mean of 8.27 and standard deviation of 0.76 .

\section{STRUCTURAL MODEL}

Path coefficients indicate the direct effect among variables is obtained through PLS algorithm calculation. Since PLSSEM does not assume the data as normally distributed, it needs to rely on a non-parametric bootstrap procedure of 5,000 (Davison \& Hinkley 1997) as the preferred means to test the significance (t-value) of the estimated path coefficients in PLS-SEM (Henseler \& Fassott 2009). The four key assessments in PLS-SEM that are commonly used: 1) structural model path coefficient, 2) coefficients of determination $\left.\left(\mathrm{R}^{2}\right), 3\right)$ effect size $\left(\mathrm{f}^{2}\right)$ and 4$)$ predictive relevance $\left(Q^{2}\right)$ (Hair et al. 2017). These assessments are used to evaluate and interpret the data for this study. Table 4 shows the results from hypotheses testing.

TABLE 4. Hypotheses testing results

\begin{tabular}{|c|c|c|c|c|c|c|c|c|c|c|c|}
\hline Hypotheses & Relationship & $\begin{array}{c}\text { Std } \\
\text { Beta }\end{array}$ & $\begin{array}{l}\text { Std. } \\
\text { Error }\end{array}$ & t-Values & p- Values & Decision & $\begin{array}{c}\text { BCI } \\
\text { LL }\end{array}$ & $\begin{array}{c}\text { BCI } \\
\text { UL }\end{array}$ & $\mathrm{R}^{2}$ & $\mathrm{f}^{2}$ & $\mathrm{Q}^{2}$ \\
\hline $\mathrm{H}_{1}$ & FB $->$ CSER & 0.201 & 0.077 & $2.607 * * *$ & 0.005 & Supported & 0.077 & 0.332 & 0.375 & 0.058 & 0.314 \\
\hline $\mathrm{H}_{2}$ & BI $->$ CSER & 0.130 & 0.078 & $1.657^{* *}$ & 0.049 & Supported & 0.001 & 0.257 & & 0.022 & \\
\hline $\mathrm{H}_{3}$ & BS -> CSER & 0.036 & 0.081 & 0.442 & 0.329 & Not Supported & -0.096 & 0.172 & & 0.002 & \\
\hline $\mathrm{H}_{4}$ & CC $->$ CSER & 0.445 & 0.063 & $7.106^{* * *}$ & 0.000 & Supported & 0.342 & 0.545 & & 0.294 & \\
\hline
\end{tabular}

Note: Significant level at one-tailed $* \mathrm{p}<0.1 ; * * \mathrm{p}<0.05$; *** $<0.01$; We use $95 \%$ confidence interval with a bootstrapping of 5,000

The structural model path coefficient is the structural model relationship representing the hypothesized relationships among variables. The path coefficient is significant at certain error probability when the empirical t-value is greater than the critical value which the critical value for one-tailed test is commonly 1.645 with the significance level at 95\% (Hair et al. 2017). There are positive significant relationships referring the path coefficient and p-value: FB to CSER (path coefficient $=$ $0.201, p<0.05$ ), BI to CSER (path coefficient $=0.13, p$ $<0.05$ ), and CC to CSER (path coefficient $=0.445, \mathrm{p}<$ $0.05)$.

Nevertheless, both board independence (BI) and family ownership (FAM) show insignificant relationship with CSER with the path coefficient $=0.036, \mathrm{p}>0.05$ and path coefficient $=0.003, \mathrm{p}>0.05$. Hence, $\mathrm{H}_{1}, \mathrm{H}_{2}$ and $\mathrm{H}_{4}$ are supported whereas $\mathrm{H}_{3}$ and $\mathrm{H}_{5}$ are not supported.

The coefficient $\left(\mathrm{R}^{2}\right)$ is 0.375 , which indicates $37.5 \%$ of variance in the CSER is explained by all exogenous constructs (female on board, board independence, board size, CSR committee and family ownership) that are linked to it. The coefficient of 0.375 is moderate given the classification by Chin (1998) that is the association is considered weak at 0.19 , moderate at 0.33 and substantial at 0.67 . For the effect size $\left(\mathrm{f}^{2}\right)$, it has been classified that $0.02,0.15$ and 0.35 are respectively small, medium and large by Cohen (1988), and the $\mathrm{f}^{2}$ less than 0.02 indicates no effect. For this study, CSR committee (CC) $\mathrm{f}^{2}$ is medium with the value of 0.294 , FB and BI $\mathrm{f}^{2}$ are small with respective values of 0.058 and 0.022 , whereas BS $\mathrm{f}^{2}$ is less than 0.02 .

For predictive accuracy, besides evaluating the magnitude of $\mathrm{R}^{2}$, predictive relevance $\left(\mathrm{Q}^{2}\right)$ is also used. Predictive relevance $\left(\mathrm{Q}^{2}\right)$ is using the cross-validated redundancy as a measure to predict the eliminated data points (Hair et al. 2017), and is computed using blindfolding procedure for a specified omission distance $\mathrm{D}$, which is 7 in this study. This model supports predictive relevance with the value of 0.314 for dependent construct (CSER) when $\mathrm{Q}^{2}$ is greater than zero (Hair et al. 2017). Figure 1 illustrates the relationship in a structural path format. 


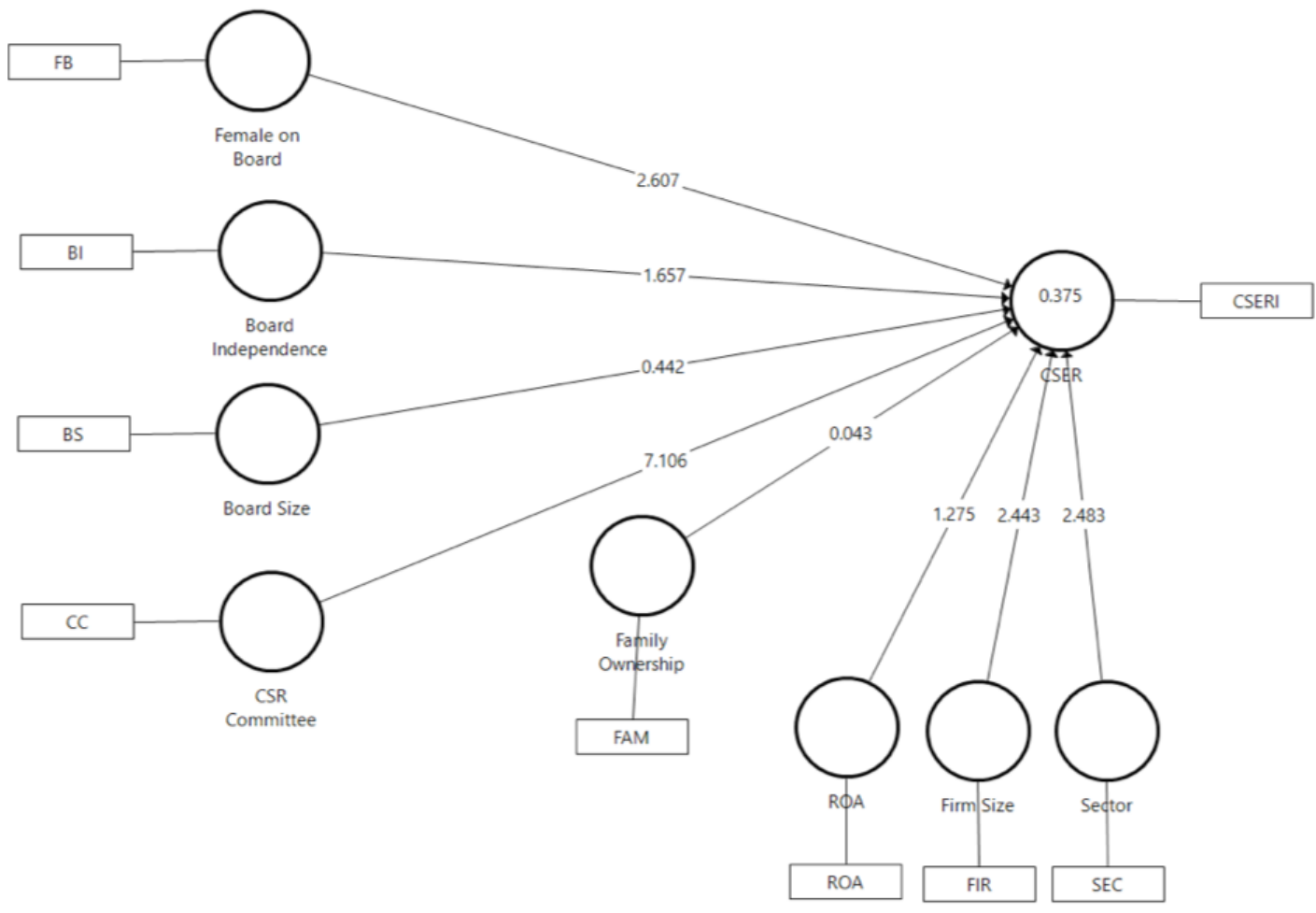

FIGURE 1. Structural model

Structural model with moderating effect is constructed by introducing the interaction terms which are (1) FB and FAM, (2) BI and FAM, (3) BS and FAM, (4) CC and FAM. The t-values ( $p$ values) for hypotheses $\mathrm{H}_{5 \mathrm{a}}, \mathrm{H}_{5 \mathrm{~b}}, \mathrm{H}_{5 \mathrm{c}}$ and $\mathrm{H}_{5 \mathrm{~d}}$ are respectively $0.789(\mathrm{p}>0.05)$, $0.752(\mathrm{p}>0.05), 1.306(\mathrm{p}>0.05)$ and $0.012(\mathrm{p}>0.05)$, all are less than 1.96 for $95 \%$ two-tailed test. Apparently, all the moderation role hypotheses $\left(\mathrm{H}_{5 \mathrm{a}}, \mathrm{H}_{5 \mathrm{~b}}, \mathrm{H}_{5 \mathrm{c}}\right.$ and $\left.\mathrm{H}_{5 \mathrm{~d}}\right)$ are not supported. To be specific the interaction terms of FB*FAM, BI*FAM, BS*FAM and CC*FAM are having insignificant relationship with CSER. The direction of the relationship is however as hypothesized that is FAM weaken the relationship between board characteristics and corporate social and environmental reporting except for board independence $\left(\mathrm{H}_{5 \mathrm{~b}}\right)$. The result indicates that the relationship between board independence is enhanced in family-owned companies, although not significant. Table 5 presents the result of moderating analysis and Figure 2 depicts the result in diagrammatical format.

TABLE 5. Moderator analysis results

\begin{tabular}{cccccccccccc}
\hline Hypotheses & \multirow{2}{*}{ Relationship } & $\begin{array}{c}\text { Std } \\
\text { Beta }\end{array}$ & $\begin{array}{c}\text { Std. } \\
\text { Error }\end{array}$ & t-Values & p-Values & Decision & $\begin{array}{c}\text { BCI } \\
\text { LL }\end{array}$ & $\begin{array}{c}\text { BCI } \\
\text { UL }\end{array}$ & $\mathrm{R}^{2}$ & $\mathrm{f}^{2}$ & $\mathrm{Q}^{2}$ \\
\hline H5a & FAM*FB -> CSER & 0.201 & 0.077 & $2.607^{* * *}$ & 0.005 & Supported & 0.077 & 0.332 & 0.375 & 0.058 & 0.314 \\
H5b & FAM*BI -> CSER $^{*} 0.130$ & 0.078 & $1.657^{* *}$ & 0.049 & Supported & 0.001 & 0.257 & & 0.022 & \\
H5c & FAM*BS - CSER $^{*} 0.036$ & 0.081 & 0.442 & 0.329 & Not Supported & -0.096 & 0.172 & & 0.002 & \\
H5d & FAM*CC -> CSER $^{*} 0.445$ & 0.063 & $7.106^{* * *}$ & 0.000 & Supported & 0.342 & 0.545 & 0.294 & \\
\hline
\end{tabular}

Note: Significant level at one-tailed ${ }^{*} \mathrm{p}<0.1 ; * * \mathrm{p}<0.05 ; * * * \mathrm{p}<0.01$; We use $95 \%$ confidence interval with a bootstrapping of 5,000 


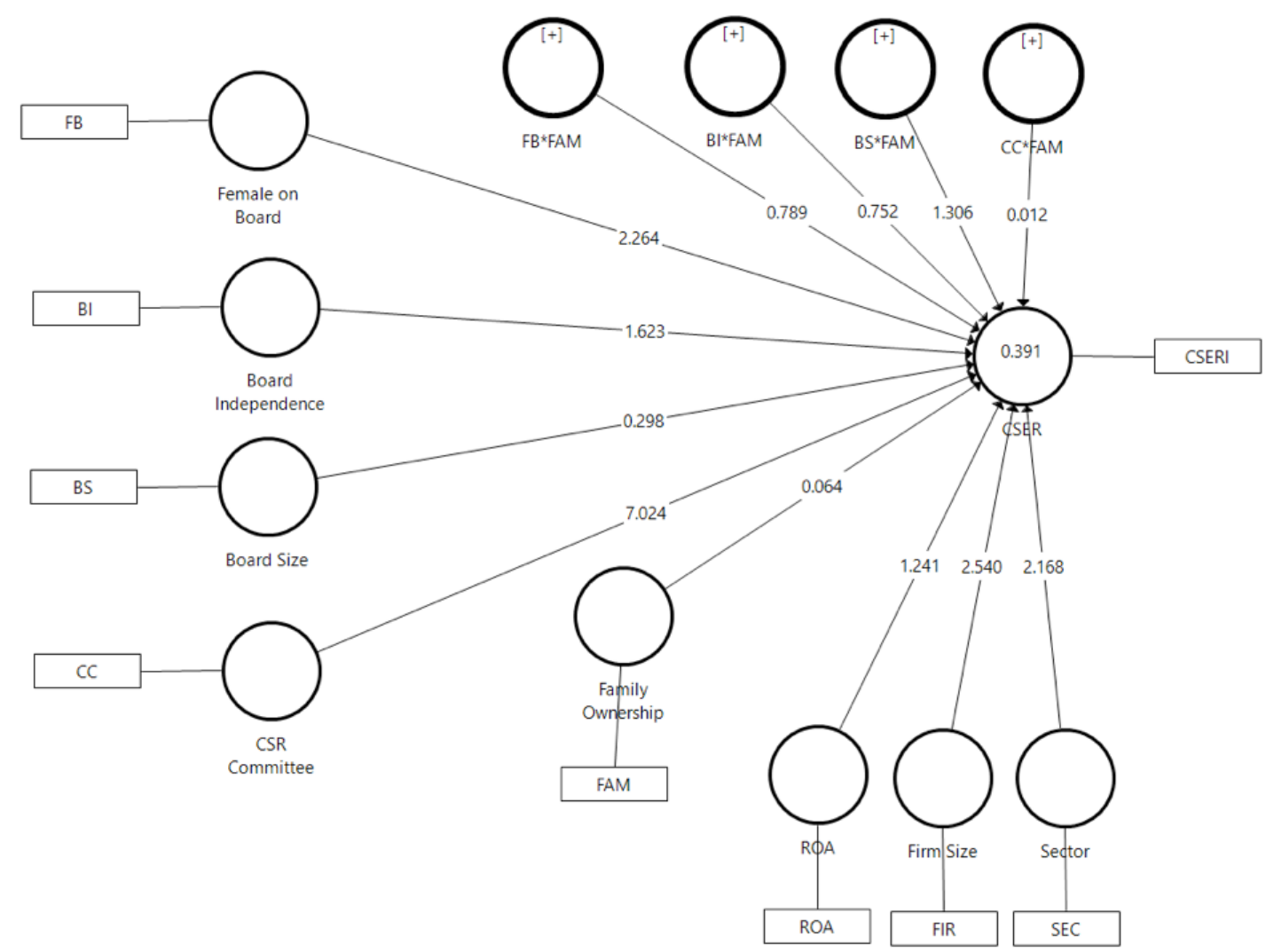

FIGURE 2. PLS structure model for t-value with moderating effects

\section{DISCUSSION}

Generally, companies are expected to disclose all related information regarding the relevant CSER practices to enable stakeholders and public communities to evaluate and measure the impact of the company's activities on the social and environment. There are about $61 \%$, that is 83 companies of 136 companies included in the sample that disclose more than $50 \%$ of the CSE information based on the developed CSER checklist. The disclosure on average is $59 \%$ and the highest disclosure score is $95 \%$ with the lowest $0 \%$ disclosure. The highest disclosure scores are contributed by 2 companies out of 136 sampled companies.

The results somehow contradicted previous findings, such as Fatima et al. (2015) that focuses on Malaysia listed companies in the environmental sensitive industry (ESI) for the environmental disclosure from 20052009 where the results show that $89 \%$ of 164 sampled companies showed higher disclosure. This is probably because the sample in Fatima et al. (2015) is from the environmentally sensitive industry, hence the disclosure of such information is much more important compared to our study. Nevertheless, as reported in Sustainability
Reporting in ASEAN Countries project published in 2018, although Malaysia obtained the highest disclosure rating (64.5\%) compared to Indonesia, Philippines, Singapore, and Thailand, it still aims for higher disclosure as higher disclosure is preferable in order to support global SDG goals. Higher disclosure is preferable as this will help the stakeholder especially the public such as investor, regulator, and civil society organization to understand more on companies' social and environmental practices in relation to strategies, plans and activities. The disclosure enables not only these stakeholders but also the companies themselves to move forward to act and propose innovative solution to combat the social and environmental issues globally.

The significant relationship between female on board and CSER is consistent with previous findings such as Phua and Chua (2017) and Dienes and Velte (2016). Female directors are seen to be more inclined towards corporate social performance and able to enhance corporate reputation through CSR initiatives as well as higher CSER. Although the results show significant positive relationship with CSER, the existence of female on board on average is only $15 \%$, far from the targeted $30 \%$ set by the government. This study reveals that 
female on board is relatively important, contributing to a significant positive relationship with CSER and it is not just for the gender diversity requirement. Based on the findings in this study, the call to increase woman participation in the board of directors is justified because they can contribute towards better conduct of companies.

The result on board independence is consistent with past studies in Malaysia, for example Htay et al. (2012) and Akhtaruddin et al. (2009) on the social and environmental disclosure. In this study, there is on average $50 \%$ of independent directors in the BOD. Independent directors are expected to monitor the management team to act in the best interest of both shareholders and stakeholders. Independent directors tend to encourage companies to publish more relevant information to the stakeholders (Certo et al. 2001), thus increases the disclosure level. This finding supports the call to have at least one third of the board members to be independent. Independent directors are proven to function more objectively and hence can lead the companies towards better performance whether financially or non-financially such as in the case of higher disclosure. This study provides empirical evidence that independent directors contribute towards higher CSE disclosure.

The third hypothesis regarding board size is not supported although it is in the hypothesized direction. The board size is expected to contribute to the variety of experiences, technical background and opinions and hence may enhance the CSER level. The finding is in contrast with another study in Malaysia (Zulkiflee 2016) that shows significant positive relationship between board size and disclosure level. Although board size has insignificant relationship with the CSER level, the effective communication among members in the board including for matters relating to CSER disclosure and initiatives should not be neglected as discussed previously.

CSR or sustainability committee is not mandated in Malaysia. However, $85.29 \%$ of companies in our sample have CSR committee in place. CSR committee is expected to stimulate management, oversee the company's CSR activities and disclosure practices on behalf of the principal's interest. Our study shows that CSR committee is positively and significantly related to CSER consistent with Diez and Odriozola (2019). Based on agency theory, CSR committee acts on behalf of the shareholders, able to reduce the agency conflict and subsequently support the CSER practices. Furthermore, the existence of CSR committee symbolizes the board orientation and commitment towards sustainable development and encourage the companies to act positively and stimulate the CSER practices and disclosure.

The results on the role of family ownership in the relationship between board characteristics and CSER are not significant. Past studies on the relationship between family ownership and disclosure level including on CSE show mixed findings. For example, Abdullah et al. (2011) show that there is negative relationship between family ownership and CSE disclosure in Malaysia, but Al-Shammari and Al-Sultan (2010) as well as Ghazali and Weetman (2006) find insignificant relationship between family ownership and voluntary disclosure. As discussed earlier, based on agency theory and the more common findings that show negative relationship between family ownership and disclosure, we hypothesize that family ownership will weaken the relationship between board characteristics and CSER. The results show that family ownership does somehow weaken the relationship between board characteristics and CSER except for board independence, although not significant. In other words, family ownership does not play significant role in weakening the CSER disclosure level, suggesting that the BOD plays effective role in monitoring the company irrespective of ownership structure. This finding shed positive light on the effectiveness of the board of directors in Malaysia.

\section{Conclusion}

In line with sustainable development goals (SDG), corporate social and environmental responsibility is encouraged in order to better manage our environment and social problems. Companies that engage in CSE should be encouraged to disclose or report their initiatives in order to encourage others to follow suit. Disclosure of CSE initiatives can be seen from the perspective of legitimacy, signaling or institutional theory. Irrespective of the intention for such disclosure, reporting of CSE or higher CSER should be encouraged because this will lead to a more informed decision made by stakeholders. Hence, it is important to know the determinants of CSER so that the authority can put in measures that can encourage CSER. Findings from this study show that board characteristics especially female on board, board independence and CSR committee significantly contribute to CSER. The findings also show that the board functions effectively in Malaysia in the sense that the board is able to positively influence CSER irrespective of pressure from family owner.

Although the CSR or sustainability disclosures have been outlined in Bursa Malaysia's listing requirements and Sustainability Report Guide (2nd Edition), the disclosure content are still on voluntary basis. This study solely retrieves data on electronic annual report without considering other data sources. Since the disclosure content is not clearly prescribed in the listing outline, company may disclose 'extra' information in other sources for example website, news, forum and so on. Future studies are recommended to expand the sources of CSE information to include other channels besides annual report.

There are many factors that contribute to the disclosures level as indicated in past studies. Findings from this study can also be useful to relevant parties in reviewing current requirements, standards or policies related to CSER. This study provides added value to current literature by introducing the family ownership as 
a potential moderator into the relationship between board characteristics and CSER. Given that we measure family ownership as percentage of family member in board, the relevant authority may need to look into whether or not to limit number of family member to be allowed as directors in BOD. Although our results show that family member is not able to exert significant influence on the board, but there is influence nevertheless. Thus, regulators and policy makers may need to consider specific corporate governance mechanism in order to allow the board to function effectively including in encouraging more CSER disclosure. The results of this study however should be interpreted with caution because it is not without limitation. This study is designed as a crosssectional study with 136 companies included as sample, constituting only $18.5 \%$ of total companies listed on the Main Market of Bursa Malaysia. This somehow may limit the generalization of the results.

\section{ACKNOWLEDGEMENT}

This work was supported by the research grant received from TEKUN Nasional (24/12/2018-25/10/2021).

\section{REFERENCES}

Abdullah, S. N., Mohamad, N. R. \& Mokhtar, M. Z. 2011. Board independence, ownership and CSR of Malaysian large firms. Corporate Ownership and Control 8(3): 417-435.

Adams, C.A. 2002. Organisational factors influencing corporate social and ethical reporting. Accounting. Auditing and Accountability Journal 15(2): 223-250.

Aggarwal, R \& Ranganathan, P. 2019. Study Designs: Part 2 Descriptive Studies. Perspectives in Clinical Research 10 (1): 34-36.

Ahmad, N.B.J, Rashid, A. \& Gow, J. 2018. Corporate board gender diversity and corporate social responsibility reporting in Malaysia. Gender Technology and Development 22(2): 87-108.

Ainon R. 2018. Ownership and governance of Malaysian firms and their impact on firm performance: A preliminary study. International Review of Management and Marketing 9(1): $1-12$.

Akbas, H.M. 2016. The relationship between board characteristics and environmental disclosure: Evidence from Turkish listed companies. South East European Journal of Economics and Business 11(2): 7-9.

Akhtaruddin, M., Hossain, M. A., Hossain, M. \& Yao, L. 2009. Corporate governance and voluntary disclosure in corporate annual reports of Malaysian listed firms. Journal of Applied Management Accounting Research 7(1): 1-19.

Al-Shammari, B. \& Al-Sultan, W. 2010. Corporate governance and voluntary disclosure in Kuwait. International Journal of Disclosure and Governance 7(3): 262-280.

Alhazmi, A. N. A. S. 2017. Exploring the factors and effects of corporate social responsibility disclosure in Saudi Arabia (in the area of accounting and finance). Doctoral dissertation. Nottingham Trent University, United Kingdom).
Ali, W. \& Rizwan, M. 2013. Factors influencing corporate social and environmental disclosure (CSED) practices in the developing countries: An institutional theoretical perspective. International Journal of Asian Social Science 3(3): 590-609.

Alshareef, M-N. Z. \& Sandhu, K. 2015. Integrating Corporate Social Responsibility (CSR) into corporate governance structure: The effect of board diversity and roles-a case study of Saudi Arabia. International Journal of Business and Management 10(7): 1-15.

Amran, N.A. 2010. Corporate governance mechanisms, succession planning and firm performance: Evidence from Malaysian family and non-family-controlled companies. Unpublished Doctoral Dissertation. Universiti Utara Malaysia, Malaysia.

Anas, A., Abdul-Rashid, H.M. \& Annuar, H.A. 2015. The effect of award on CSR disclosures in annual reports of Malaysian PLCs. Social Responsibility Journal 11(4): 831-852.

Azmi, I.A.G. \& Barrett, M.A. 2013. Women on Boards and Company Financial Performance: A Study of Malaysian SMEs. In Proceedings Of $3^{\text {rd }}$ Global Accounting, Finance and Economics Conference, Melbourne: World Business Institute. https://wbiworldconpro.com/uploads/melbourneconference-2013/finance/1367487777_346-Ilhaamie.pdf

Bani-Khalid, T., Kouhy, R. \& Hassan, A. 2017. The impact of corporate characteristics on social and environmental disclosure (CSED): The case of Jordan. Journal of Accounting and Auditing: Research \& Practice: 1-28.

Baraibar-Diez, E. \& Odriozola, M.D. 2019. CSR committees and their effect on ESG performance in UK, France. Germany and Spain. Sustainability 11(18): 1-20.

Barako, D. G., Hancock, P. \& Izan, H. Y. 2006. Factors influencing voluntary corporate disclosure by Kenyan companies. Corporate Governance: An International Review 14 (2): 107-125.

Barclay, D., Higgins, C. \& Thompson, R. 1995. The partial least squares (PLS) approach to causal modeling: Personal computer adoption and use as an illustration. Technology Studies 2(2): 285-309.

Bukair, A.A. \& Abdul-Rahman, A. 2015. The effect of the board of directors' characteristics on corporate social responsibility disclosure by Islamic banks. Journal of Management Research 7(2): 506-519.

Buniamin, S., Alrazi, B., Johari, N.H. \& Rahman, N.R.A. 2008. Corporate governance and environmental reporting in Malaysia. Asian Journal of Business and Accounting 1(2): 65-88.

Buniamin, S., Alrazi, B., Johari, N.H., Raida, N. \& Rahman, A. 2011. Corporate governance practices and environmental reporting of companies in Malaysia: Finding possibilities of double thumbs up. Jurnal Pengurusan 32: 55-71.

Certo, S.T., Covin, J.G., Daily, C.M. \& Dalton, D.R. 2001. Wealth and the effects of founder management among IPO stage new ventures. Strategic Management Journal 22 (6-7): 641-658.

Channelnewsasia. 2020. https://www.channelnewsasia.com/ news/asia/malaysia-top-glove-timeline-profits-banworkers-housing

Chapple, W. \& Moon, J. 2005. Corporate Social Responsibility (CSR) in Asia: A seven-country study of CSR web site reporting. Business \& Society 44(4): 415-441. 
Chen, J.P. \& Jaggi, B.L. 2000. The association between independent non-executive directors, family control and financial disclosures. Journal of Accounting and Public Policy 19(5): 285-310.

Cheng, Q. 2014. Family firm research - A review. China Journal of Accounting Research 7(3): 149-163.

Chin, W.W. 1998. The partial least squares approach for structural equation modeling. In Modern Methods for Business Research, edited by G.A. Marcoulides, 295-336. New York: Psychology Press.

Coles, J. L., Daniel, N. D. \& Naveen, L. 2008. Boards: Does one size fit all? Journal of Financial Economics 87(2): 329356.

Davison, A. C. \& Hinkley, D. V. 1997. Bootstrap Methods and Their Application. Cambridge University Press: Cambridge.

Dienes, D. \& Velte, P. 2016. The Impact of Supervisory Board Composition on CSR Reporting. Evidence from the German Two-tier System. Sustainability 8(1): 1-20.

Eisenhardt, K. M. 1989. Agency theory: An assessment and review. Academy of Management Review 14(1): 57-74.

Esa, E., Anum, N. \& Ghazali, M. 2012. Corporate social responsibility and corporate governance in Malaysian Government-linked Companies. Corporate Governance 12 (3): 292-305.

Fama, E. \& Jensen, M. 1983. Separation of ownership and control. Journal of Law and Economics 26(2): 301-325.

Fatima A.H, Abdullah N. \& Sulaiman M. 2015. Environmental disclosure quality: Examining the impact of the stock exchange of Malaysia's listing requirements. Social Responsibility Journal 11(4): 904-922.

Fauzi, F. \& Locke, S. 2012. Board structure, ownership structure and firm performance: A study of New Zealand listed-firms. Asian Academy of Management Journal of Accounting and Finance 8(2): 43-67.

Ghabayen, M.A., Mohamad, N.R. \& Ahmad, N. 2016. Board characteristics and corporate social responsibility disclosure in the Jordanian banks. Corporate Board: Role, Duties and Composition 12(1): 84-100.

Ganesan, Y., Hashim F. \& Jaafar A.M. 2017. Corporate governance and sustainability reporting practices: The moderating role of internal audit function. Global Business and Management Research: An International Journal 9(4): 159-179.

Ghazali N.A.M. 2007. Ownership structure and corporate social responsibility disclosure: Some Malaysian evidence. Corporate Governance 7(3): 251-266.

Ghazali, N.A.M. \& Weetman, P. 2006. Perpetuating traditional inferences: Voluntary disclosure in Malaysia following the economic crisis. Journal of International Accounting, Auditing and Taxation 15 (2): 226-248.

Giannarakis, G. 2014. Corporate governance and financial characteristic effects on the extent of corporate social responsibility disclosure. Social Responsibility Journal 10(4): 569-590.

Gray, R., Javad, M., Power, D. M. \& Sinclair, C. D. 2001. Social and environmental disclosure and corporate characteristics: A research note and extension. Journal of Business, Finance \& Accounting 28(3-4): 327-356.

Haider, M.B. 2010. An overview of corporate social and environmental reporting (CSER) in developing countries. Issues in Social and Environmental Accounting 4(1): 3-17.
Hair, J.F., Hult, G.T.M., Ringle, C.M. \& Sarstedt, M. 2017. A Primer on Partial Least Squares Structural Equation Modeling (PLS-SEM). $2^{\text {nd }}$ ed. Thousand Oaks, CA: Sage Publications Ltd.

Haniffa, R.M. \& Cooke, T.E. 2005. The impact of culture and governance on corporate social reporting. Journal of Accounting and Public Policy 24(5): 391-430.

Hashim, F., Azlan, A. \& Mahadi, D. 2015. Corporate governance and sustainability practices in Islamic financial institutions: The role of country of origin. Procedia Economics and Finance 31(15): 36-43.

Hamid, F.Z.A. \& Atan, R. 2011. Corporate social responsibility by the Malaysian Telecommunication firms. International Journal of Business and Social Science 2(5): 198-208.

Henseler, J. \& Fassott 2009. Testing moderating effects in PLS Path Models: An illustration of available procedures. Handbook of Partial Least Squares: 713-735.

Hillman, A. J. \&T. Dalziel 2003. Boards of directors and firm performance: Integrating agency and resource dependence perspectives. Academy of Management Review 28(3): 383-396.

Ho, J.L. \& Kang, F, 2013. Auditor choice and audit fees in family firms: Evidence from the S\&P 1500. Auditing: A Journal of Practice \& Theory 32(4): 71-93.

Ho, S.S.M \& Wong, K.S. 2001. A study of the relationship between corporate governance structures and the extent of voluntary disclosure. Journal of International Accounting, Auditing and Taxation 10(2): 139-156.

Htay, S.N.N., Rashid, H.M.A., Adnan, M.A., \& Meera, A.K.M. 2012. Impact of corporate governance on social and environmental information disclosure of Malaysian listed banks: Panel data analysis. Asian Journal of Finance \& Accounting 4(1): 1-24.

Huafang, X. \& Jianguo, Y. 2007. Ownership structure, board composition and corporate voluntary disclosure. Evidence from listed companies in China. Managerial Auditing Journal 22(6): 604-619.

Hussain, N., Rigoni U. \& Orij R.P. 2018. Corporate governance and sustainability performance: Analysis of triple bottom line performance. Journal of Business Ethics 149(2): 411-432.

Ibrahim, H. \& Samad, F.A. 2010. Family business in emerging markets: The case of Malaysia. Journal of Business Management 4(13): 2586-2595.

Intan Maiza A.R. \& Ku Nor Izah K.I. 2016. Do representation of women directors and their demographic characteristics affect CSR disclosure? Evidence from Malaysia. Business, Management and Economics Research 2(4): 81-89.

Janggu, T., Darus, F., Zain, M. M. \& Sawani, Y. 2014. Does good corporate governance lead to better sustainability reporting? An analysis using Structural Equation Modeling. Procedia: Social and Behavioral Sciences 145: 138-145.

John, K. \& Senbet, L.W. 1998. Corporate governance and board effectiveness. Journal of Banking \& Finance 22(4): 371-403.

Joseph, C. 2010. Content analysis of sustainability reporting on Malaysia local authority websites. Journal of Administrative Science 7(1): 101-125.

Khan, A., Siddiqui, J. \& Muttakin, M.B. 2012. Corporate governance and corporate social responsibility disclosures: Evidence from an emerging economy. Journal of Business Ethics 114(2): 207-223 
Kilian \& Hennigs. 2014. Corporate social responsibility and environmental reporting in controversial industries. European Business Review 26(1): 79-101.

Liu, Y., Wei, Z. \& Xie, F. 2016. CFO gender and earnings management: Evidence from China. Review of Quantitative Finance and Accounting 46(4): 881-905.

Mamun, M.A, Shaikh, J.M. \& Easmin, R. 2017. Corporate social responsibility disclosure in Malaysian business. Academy of Strategy Management Journal 16(2): 115-126.

Masud, M.A.K, Nurunnabi, M. \& Bae, S.M. 2018. The effects of corporate governance on environmental sustainability reporting: Empirical evidence from South Asian Countries. Asian Journal of Sustainability and Social Responsibility 3(3): 1-26.

Mazurina M.A. \& Taylor, D. 2014. Content analysis of corporate risk disclosure in Malaysia. $4^{\text {th }}$ Annual International Conference on Accounting and Finance (AF2014). Phuket, Thailand.

Nielsen, S. \& Huse, M. 2010. The Contribution of women on boards of directors: Going beyond the surface. Corporate Governance: An International Review 18(2): 136-148.

Noradiva H. \& Maizatulakma A. 2018. Stakeholder power towards corporate social and environmental responsibility disclosure: Evidence from Malaysia. Asian Journal of Accounting and Governance 10: 1-10.

Persson, K. \& Vingren, T. 2017. Factors affecting the sustainability disclosures in swedish state-owned enterprises as hybrid organizations. Master Thesis. Kristianstad University, Sweden.

Price Waterhouse Coopers, PWC 2016. Family Business Survey 2016: The Malaysian Chapter. Retrieved from https:// www.pwc.com/my/en/assets/publications/2016-familybusiness-survey-malaysianchapter.pd

Rafique, M. A., Malik, Q. A., Waheed, A. \& Khan, N.-U. 2017. Corporate governance and environmental reporting in Pakistan. Pakistan Administrative Review 1(2): 103-114.

Rao, K. K., Tilt, C. A. \& Lester, L. H. 2012. Corporate governance and environmental reporting: An Australian study. Corporate Governance: The International Journal of Business in Society 12(2): 143-163.

Rehman, R.U., Ikram A. \& Malik F. 2017. Impact of board characteristics on corporate social responsibility disclosure. Journal of Applied Business Research 33(4): 799-811.

Rosli, M.H.B. \& Mohd, F.B. 2015. Determinants of CSR disclosure: A study on Malaysia public listed companies. Journal of Applied Business and Economic 1: 1-11.

Rosli, M.H.B. \& Mohd, F.B. 2018. Profitability, share return, company size, industry type and corporate social responsibility disclosure of Malaysian public listed companies. International Journal of Engineering \& Technology 7(3.35): 280-284.

Rouf, M.A. \& Hossan, M.A. 2020. The effects of board size and board composition on CSR disclosure: a study of banking sectors in Bangladesh. International Journal of Ethics and Systems 36(4). doi:org/10.1108/IJOES-06-2020-0079

Saha, A.K. \& Akter, S. 2013. Corporate governance and voluntary disclosure practices of financial non-financial sector companies in Bangladesh. Journal of Applied Management Accounting Research 11(2): 45-61.

Said, R., Zainuddin, Y. H. \& Haron, H. 2009. The relationship between corporate social responsibility disclosure and corporate governance characteristics in Malaysian public listed companies. Social Responsibility Journal 5(2): 212-226.
Securities Commission Malaysia 2017. Malaysian Code on Corporate Governance. Retrieved from: https:// www.sc.com.my/api/documentms/download ashx?id=70a5568b-1937-4d2b-8cbf-3aefed112c0a

Shil, N.C. \& Paramanik, A.K. 2009. A look into the disclosure improvements for CSR Reporting in Bangladesh. Malaysia Accounting Review 8(2): 67-83.

Statista 2020. Percentage of Women on Boards of Directors in Malaysia from 2010 to 2019. Retrieved from: https://www. statista.com/statistics/668436/malaysia-share-femaleboard-directors

Sundarasen, S.D.D., Je-Yen T. \& Rajanngam, N. 2016. Board composition and corporate social responsibility in an emerging market. Corporate Governance International Journal of Business in Society 16(1): 35-53.

Sweeney, L. \& Coughlan, J. 2008. Do different industries report corporate social responsibility differently? An investigation through the Lens of Stakeholder Theory. Journal of Marketing Communications 14(2): 113-124.

Xie, J. 2018. An empirical study on the relationship between female executives and corporate philanthropy: From the Enterprise life cycle perspective. Modern Economy 9(1): 149-159.

Yap, L-K., Chan, S-G. \& Zainudin, R. 2017. Gender diversity and firms' financial Performance in Malaysia. Asian Academy of Management Journal of Accounting and Finance 13(1): 41-62.

Yasser, Q. R. 2011. Challenges in corporate governance-A family controlled business prospective. International Journal of Innovation, Management and Technology 2(1) 73-76.

Yusoff, H., Ahman, Z. \& Darus F. 2019. the influence of corporate governance on corporate social responsibility disclosure: A focus on accountability. Academy of Accounting and Financial Studies Journal 23 (1): 1-16.

Zulkiflee, M.R. 2016. The effect of board characteristics on corporate social responsibility (CSR) disclosure. Journal on Vocational and Technical Education 1(1): 1-10.

Fathyah Hashim

Graduate School of Business

Universiti Sains Malaysia

1800 USM Pulau Pinang

MALAYSIA.

E-mail: fathashim@usm.my

Zaini Embong*

Faculty of Economics and Business

Universiti Kebangsaan Malaysia

43600 UKM Bangi, Selangor

MALAYSIA.

E-mail: zainiembong@ukm.my

Wang Boon Phoey

Bestworld Engineering Sdn. Bhd.

Jalan Perindustrian Bukit Minyak 6,

Taman Perindustrian Bukit Minyak

14100 Simpang Ampat, Pulau Pinang

MALAYSIA.

E-mail: elvi.wbp@gmail.com

* Corresponding author 